This PDF is a selection from an out-of-print volume from the National Bureau of Economic Research

Volume Title: The Rate and Direction of Inventive Activity: Economic and Social Factors

Volume Author/Editor: Universities-National Bureau Committee for Economic Research, Committee on Economic Growth of the Social Science Research Council

Volume Publisher: Princeton University Press

Volume ISBN: 0-87014-304-2

Volume URL: http://www.nber.org/books/univ62-1

Publication Date: 1962

Chapter Title: The Changing Direction of Research and Development Employment Among Firms

Chapter Author: James S. Worley

Chapter URL: http://www.nber.org/chapters/c2119

Chapter pages in book: (p. 233 - 252) 


\title{
The Changing Direction of Research and Development Employment Among Firms
}

\author{
JAMES S. WORLEY \\ VANDERBILT UNIVERSITY
}

\section{Introduction}

THIS paper examines the participation of certain firms in the nation's research and development effort. More specifically, it focuses upon the 100 firms reported as employing the largest number of research and development personnel in 1927, 1938, 1950, and 1955. ${ }^{1}$ Selection of 100 firms for analysis in each year is, of course, arbitrary. However, the inclusion of firms with a relatively small volume of research and development employment assures us that, insofar as data are available, all of the very large employers have been included. With this goal fulfilled there is little need to undertake the considerably greater task of identifying a larger number of firms.

The nation's industrial research and development effort was relatively small in the beginning of the period under review. But a substantial increase in both the size of the effort and in the number of participating firms is evident in prewar data, and the growth has been even more pronounced in recent years, in good part because of government support to meet the demands of the cold war. Against that background this paper analyzes the changes in leadership in research and development that have occurred. So far as possible we shall ascertain the impact of the higher postwar level of government support upon the

Nore: Most of the material upon which this paper is based is presented in the writer's doctoral dissertation, "Industrial Research and Development and the New Competition -A Study of the Leading Employers of Research and Development Personnel by Industry Group and by Size of Firm," submitted to Princeton University in 1958. The writer wishes to acknowledge financial assistance from the Institute of Research and Training in the Social Sciences of Vanderbilt University, made possible by a grant from the Rockefeller Foundation, which provided time to extend the dissertation material.

1 These firms were identified by tabulating data contained in the National Research Council surveys of industrial research laboratories conducted on these dates. For a discussion of the adequacy of these surveys and of the procedure involved in tabulating the data, and for the identification of the leading firms, the reader is referred to the writer's dissertation.

The lists of the 100 largest exclude commercial and nonprofit research organizations because we wish to concentrate on those firms whose principal line of activity consists of the manufacture and sale of commodities or the sale of services other than research and development service. 
composition of the 100 leading firms. Following this we shall examine the influence of two factors that are widely believed to play an important part in determining the distribution of research and development activity and that may consequently help explain the pattern of leadership. These factors are the size of the leading firms and the variability in intensity of research effort among industries.

Before proceeding a note of caution must be issued. The study concentrates upon employment of research and development personnelthe principal input in research and development - and the findings are not intended to have output significance. Scattered evidence points to considerable variation among firms in the proportion of research and development projects that are successful as well as in the quantity of inputs per successful project. Extent of employment of research and development personnel is, therefore, not an accurate index of the rate of innovation.

We begin by briefly discussing the relative importance of the leaders, hoping to demonstrate that they have accounted for a sizeable share of industrial research and development and that their importance in this respect measures only partially their sphere of influence in the economy.

\section{Importance of the 100 Largest Employers of Research and Development Personnel}

It is well known that research and development activity today is highly concentrated in the largest firms in the economy. A high degree of concentration is also visible in earlier data, although the extent to which the largest firms were involved is revealed less clearly. ${ }^{2}$ Examination of the proportion of industrial research and development employment accounted for by the 100 largest employers and of the interrelationship between these firms and the largest firms indicates that very considerable concentration in the largest firms has typified the period since 1927.

The writer estimates that the 168,808 persons in the laboratories of the 100 largest employers in early 1955 amounted to about 40 per cent of all such personnel employed in the industrial sector at that time. The significance of this figure is apparent if we note that in 1950 the 100 largest manufacturing firms accounted for 33.3 per cent of the total

${ }^{2}$ The National Research Council data for 1920-38 have been tabulated and analyzed by George Perazich and Phillip M. Field in Industrial Research and Changing Technology (Works Progress Administration, National Research Project Number M-4, Philadelphia, 1940). 
value of product of all manufacturing industries and that the 200 largest accounted for 40.5 per cent. ${ }^{3}$ Although we are unable to estimate the share of the 100 largest before World War II with accuracy, the available evidence indicates that it was higher than it is now. ${ }^{4}$

Not only has the share of the 100 largest been substantial but also there has existed considerable inequality in the distribution of research and development employment among the leaders themselves. This is shown in Table 1. It is evident, however, that the inequality is now less marked than previously, although some ambiguity surrounds the 1955 data. Lorenz curves constructed for 1927, 1938, and 1950 lie successively closer to the diagonal line of equal distribution, but those for 1950 and 1955 intersect at a point corresponding to the twentieth largest employer, displaying (when compared to the 1950 data) greater equality among the first 20 firms in 1955 and less equality among the remaining 80 firms. By inspection it appears that the Gini coefficients for 1950 and 1955 are roughly equal, signifying no change in the overall degree of inequality within the 100 largest. Therefore it is probably more accurate to conclude that, while inequality in the distribution of employment within the 100 largest decreased substantially from 1927 to 1938 and slightly from 1938 to 1950 , no marked overall change occurred between 1950 and 1955 .

To study the extent to which the leading research and development employers have also been among the largest firms we may compare the leaders with Kaplan's lists of the 100 largest industrial companies for 1929, 1935, and 1948, ${ }^{5}$ the Federal Trade Commission list of the 1,000 largest in $1948,{ }^{6}$ and Fortune's list of the 500 largest for 1955.7 We must use assets to measure size in order to maintain consistency between the lists. In addition to the fact that only the Fortune list coincides in time with our data, the lists are not strictly comparable among themselves because of differences in the details of their

\footnotetext{
${ }^{3}$ Changes in Concentration in Manufacturing, 1935 to 1947 and 1950, Federal Trade Commission, 1954, pp. 17-18.

${ }^{4}$ It must be noted that there is a downward bias to the estimates over time. While all measures involving an absolute number of firms in the numerator are subject to some bias if the total population of firms under analysis is changing, the problem may be more acute in our case because of the sizeable growth in the number of companies conducting research and development.

${ }^{5}$ A. D. H. Kaplan, Big Enterprise in a Competitive System, Washington, The Brookings Institution, 1954, pp. 145-154.

${ }^{\circ} A$ List of 1,000 Large Manufacturing Companies, Their Subsidiaries and Affiliates, 1948, Federal Trade Commission, 1951.

'The Fortune Directory of the 500 Largest U.S. Industrial Corporations, supplement to the July 1956 issue.
} 


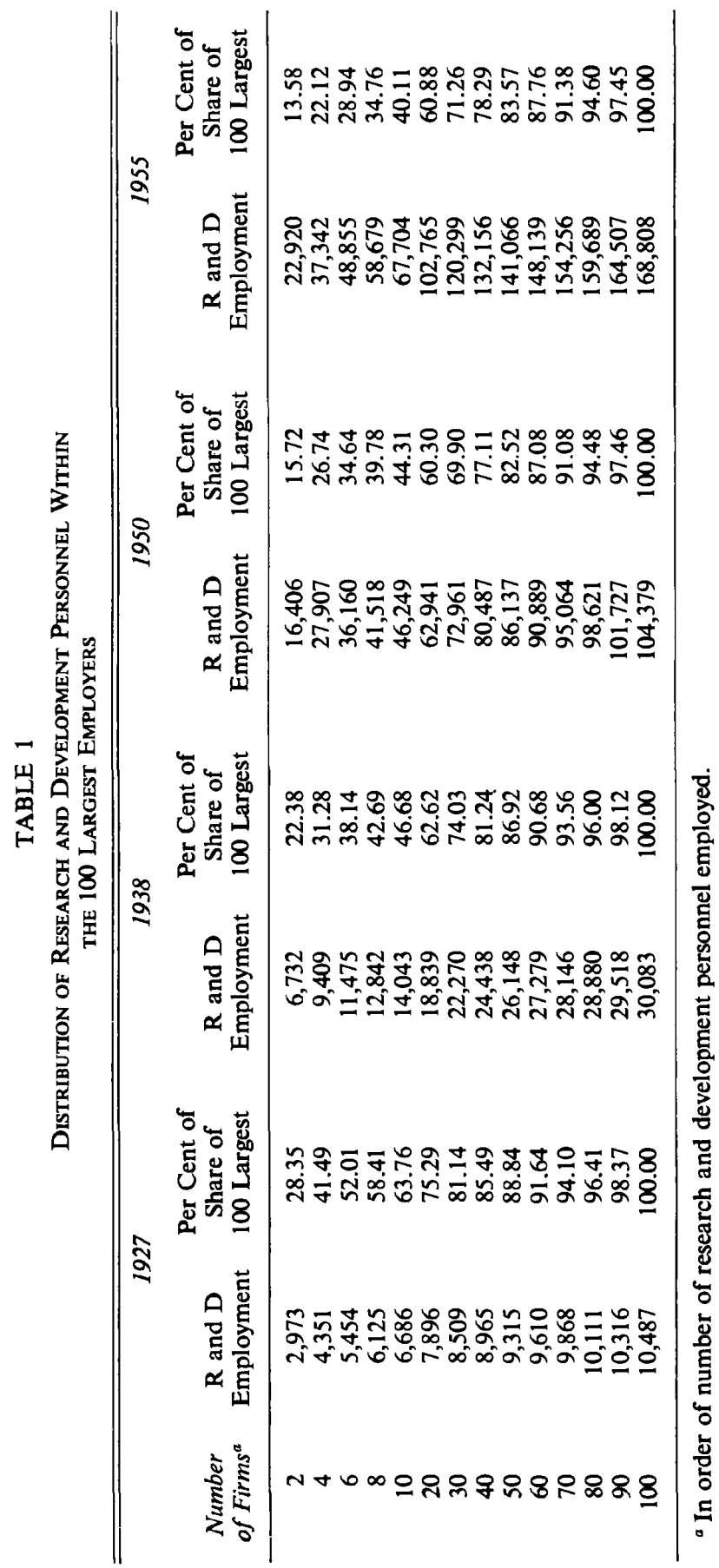


construction. Nevertheless the comparisons, though presented more precisely than the data warrant, are generally valid. They show that 36 of the research and development leaders in 1927 appeared among the 100 largest firms in 1929, 45 of the 1938 leaders were among the 100 largest firms in 1935, 45 of the 1950 leaders appeared in the 1948 list of the 100 largest, and 51 leaders were in the top 100 firms in 1955.

Most of the research and development leaders that did not rank among the 100 largest firms were, nevertheless, among the larger firms in the economy-86 of them among Fortune's 500 in 1955 . We may account for the failure of 5 others to appear in that list -3 because they did not disclose financial data, 1 because it was not primarily a manufacturing firm, and another probably because Fortune's decision to employ sales as the primary basis of selection excluded its revenue derived from leases. Similarly, 89 of the leading research and development employers in 1950 appeared among the 1,000 largest firms in 1948, and at least 6 others were absent only because they did not publish financial information or because they were not engaged in manufacturing. Inspection of the relative asset size of the research and development leaders in 1927 and 1938 suggests that many of them were among the larger firms in those years, although the relationship may have been less strong in 1927.

Thus it seems clear that there has existed a substantial overlap between the firms accounting for the concentration of research and development and those responsible for asset concentration and that the interrelationship now is probably even more pronounced than formerly.

\section{Changes in Firm and Industry Distribution of the 100 Largest}

We turn now to an examination of changes in research and development leadership. First we analyze changes in the 100 largest by industry group, and then calculate the turnover of firms among the leaders and evaluate the significance of the turnover that has occurred.

\section{DISTRIBUTION BY INDUSTRY GROUP 8}

Table 2 shows the distribution of the 100 largest $R$ and $D$ employers by industry classification. ${ }^{8}$ If we treat the nonmanufacturing sector as

\footnotetext{
${ }^{8}$ We are forced to employ a broad industry classification because the firms under analysis are among these most highly diversified. Furthermore, since research is held to be a major means of diversification, division of the firms into their constituent markets might not be an appropriate guide to allocation of their research and development programs. Unfortunately the data are not sufficient to allow us to allocate research and development activity more directly.
} 


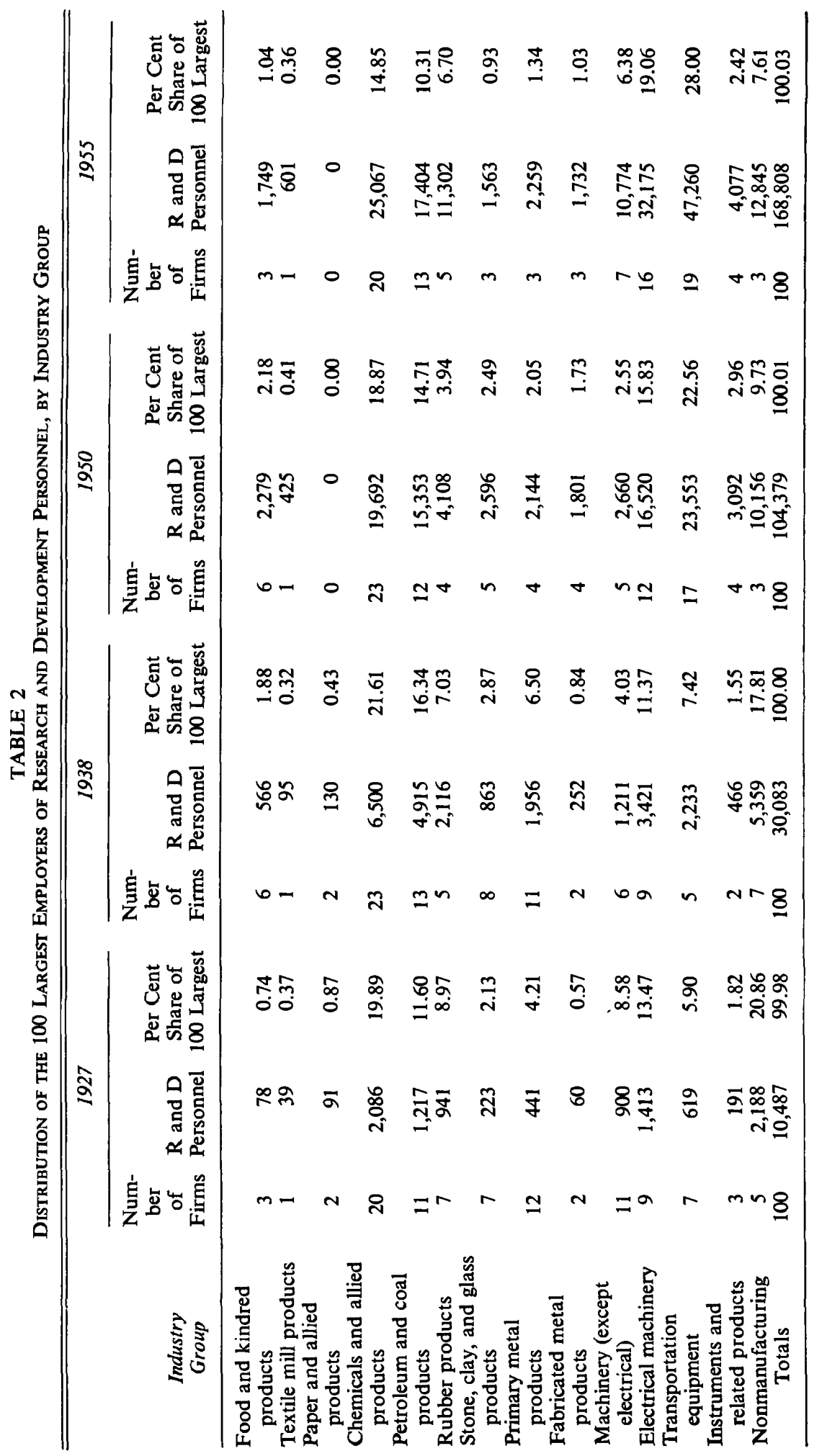


a single industry group (with reason, because electrical communication is the principal contributor to this sector's prominence), 14 industry groups were represented in 1927 and 1938 and 13 appeared in 1950 and 1955. The contribution of many of these industry groups was almost negligible, however, and the 7 leading groups in each year dominated the distribution, accounting for from 88 to 93 per cent of the total employment of the 100 leaders. Indeed, as the following tabulation shows, the 4 leading groups accounted for almost two-thirds of the total in 1927, and their share persistently increased thereafter.

1927

Per Cent

Nonmanufacturing (primarily electrical communication) $\quad 20.86$

Chemicals and allied products $\quad 19.89$

Electrical machinery

13.47

Petroleum and petroleum products $\quad 11.60$

65.82

1938

Chemicals and allied products

Nonmanufacturing (primarily electrical communication) $\quad 17.81$

Petroleum and petroleum products 16.34

Electrical machinery

1950

Transportation equipment

Chemicals and allied products

Electrical machinery

Petroleum and petroleum products

1955

Transportation equipment

Electrical machinery

Chemicals and allied products

Petroleum and petroleum products

Note also that only 5 industry groups appeared among the 4 leaders, transportation equipment replacing electrical communication in the postwar years and assuming a dominant position. Further inspection 
of Table 2 shows that between 1927 and 1955 the changes associated with these industry groups were the most marked, that the share of electrical machinery rose moderately and that of chemicals fell by roughly the same amount, and that all other changes were relatively small. Thus we are presented essentially with a picture of stability in the combined influence of certain industry groups but with important changes in leadership taking place among those groups.

The changes in the industrial composition of the leaders reflect those pertaining to all firms, although the order of leadership differs slightly. They appear to be associated primarily with the distribution of the higher postwar level of government support of research and development. According to the 1953-54 National Science Foundation survey, the federal government paid for 84.4 per cent of all research and development conducted by the aircraft industry-a major component of transportation equipment-and for 54.5 per cent of that conducted by the electrical machinery industry. On the other hand, only 2.5 per cent of all research and development expenditures in the chemical industry and 5.6 per cent of those in petroleum were financed by the government. The government's support in aircraft and electrical machinery amounted to almost $\$ 1,044$ million, about 77 per cent of its total support for all industries. ${ }^{9}$

The level of government support does not adequately explain the increased activity in motor vehicles, however, inasmuch as government financed research and development amounted to only about 10 per cent of that industry's expenditures in $1951^{10}$ and it does not seem likely that this ratio would be substantially different in other postwar years. The appearance of motor vehicles as an important spender on research and development is probably associated with the industry's rapid expansion since the 1920's and may illustrate Blank and Stigler's discovery that a substantial part (about 40 per cent) of the increase in the ratio of engineers and chemists to total employment is attributable to the faster growth of industries employing relatively more persons trained in the technological professions. ${ }^{11}$

${ }^{9}$ Science and Engineering in American Industry, Final Report on a 1953-1954 Survey, National Science Foundation 56-16, Washington, 1956, p. 17. The report points out, however, that the low figures for chemicals and petroleum are misleading because the cost of some privately-financed research and development appears in the price of finished products sold under procurement contracts to the government (p. 16).

${ }^{10}$ Scientific Research and Development in American Industry, Bureau of Labor Statistics, 1953 , p. 76. But the comment in the preceding footnote may apply here as well.

11 David M. Blank and George J. Stigler, The Demand and Supply of Scientific Personnel, Princeton University Press for National Bureau of Economic Research, 1957, pp. 48-57. 
TURNOVER OF LEADERSHIP IN RESEARCH AND DEVELOPMENT EMPLOYMENT

Forty-eight of the 100 leaders in 1927 reappeared in the 1938 list, and of the 52 firms that dropped out 8 had merged or consolidated with companies that remained among the leaders. Therefore only 44 firms failed to reappear because their employment of research and development personnel did not grow in pace with that of the other leaders. Sixty-one of the 100 largest employers of $\mathrm{R}$ and $\mathrm{D}$ personnel in 1938 reappeared in 1950 and another which had merged during the period appeared under the name of its parent, leaving a total of 38 drop-outs between 1938 and 1950. Seventy-four firms in the 1950 list reappeared in 1955. Two were excluded because of incomplete data (although the writer believes that they would have otherwise remained in the 100 largest) and mergers accounted for 4 additional disappearances. Therefore, only 20 firms dropped out because of insufficient growth in their employment of research and development personnel.

The rates of turnover from list to list-expressed on an average annual basis as the percentage of actual drop-outs to the maximum possible number of 100-were 4 per cent from 1927 to $1938,3.2$ per cent between 1938 and 1950, and 4 per cent between 1950 and 1955 . Over the entire period the average annual rate of turnover was 3.64 per cent. We cannot deduce whether this rate is high or low, since neither empirical nor theoretical grounds exist for the construction of reference data against which to judge it. However, it is substantially higher than the 2.05 per cent annual rate of turnover among the 100 largest firms in Kaplan's lists from 1929 to $1948,{ }^{12}$ indicating that there has been greater opportunity for firms to achieve prominence in research and development than for them to push into the largest size class.

The numerical rates of turnover exaggerate the importance of changes in leadership, however, since firms dropping from the lists accounted for a relatively small part of the research and development

\footnotetext{
${ }^{12}$ Calculated by the writer. Kaplan draws the conclusion that "industrial leadership at the big business level is precarious" (op. cit., p. 141). This is largely a matter of judgment, since reference data are also not available here to give an objective answer. Moreover, there is conflicting evidence. Seymour Friedland has shown that, apart from however high or low the rate of turnover may be, the composition of the 50 largest firms demonstrates increasing stability over time ("The Fifty Largest Industrial Corporations-A Study of Growth and Turnover," doctoral dissertation submitted to Harvard University, 1955).
} 
employment of the 100 largest in each year. Indeed, given the substantial inequality in the distribution of employment among the leaders, this is what one might well expect. The 44 firms that dropped out after 1927 accounted for only 13 per cent of the research and development personnel in the 1927 list. The 38 drop-outs between 1938 and 1950 accounted for 14 per cent of the total in 1938, and the 20 firms that dropped out after 1950 accounted for 8 per cent of the 1950 total. Firms that replaced the drop-outs accounted for 28 per cent, 25 per cent, and 11 per cent, respectively, of the total research and development employment in subsequent lists. Although they were relatively more important than the firms they replaced, they nevertheless accounted for less than the average number of personnel employed by each of the 100 largest.

The following tabulation shows the relative importance of the leaders in terms of the frequency of their appearance in the four lists.

\begin{tabular}{c} 
Number of \\
Companies \\
104 \\
45 \\
30 \\
29 \\
\hline 208
\end{tabular}

\begin{tabular}{c} 
Per Cent of \\
Employment \\
in All Lists \\
10 \\
20 \\
18 \\
52 \\
\hline 100
\end{tabular}

Whereas a total of 400 companies could have appeared if there had been a complete turnover from list to list, only 208 companies were actually involved. ${ }^{13}$ Of this number, 149 (over 70 per cent of the 208) accounted for only 30 per cent of the combined research and development employment of the four lists. These firms therefore affected the rate of turnover to an extent that was considerably greater than their quantitative significance among the leaders. On the other hand, the 29 firms that appeared in all lists and the 30 firms that appeared in at least three lists accounted for 70 per cent of the total employment. It seems clear that a good part of the turnover consisted of what might be described as fringe movement.

${ }^{13}$ If we take account of those cases where a firm merged with another during the period and later appeared as part of the parent company, and if we recognize the exclusion of 3 firms from one or more lists because of the absence of data, the number of companies appearing in the lists is reduced to 182. 
The role of the 59 firms that appeared three or more times deserves further attention, for the influence of this group among the 100 leaders signifies that the concentration of research and development employment has in large part been vested in the same firms throughout the period. We may call these firms consistent members of the 100 largest, since inclusion in at least three lists means that, regardless of industry classification, they survived the shift in the industry locus of research and development that took place during and after World War II. The consistent members accounted for a substantial share of each list, although their importance in recent years has declined. Those that appeared four times accounted for 70 per cent of the research and development employment in the 1927 list, for 61 per cent in 1938, 54 per cent in 1950, and 48 per cent in 1955. Inclusion of the 30 firms listed three times raises these figures to 79 per cent, 82 per cent, 74 per cent, and 64 per cent, respectively. ${ }^{\mathbf{1 4}}$

The declining share of the consistent members in the postwar period appears to be largely attributable to the expanded role of the federal government in sponsoring industrial research and development, and especially to the unequal distribution of government support among firms in various industries. Twenty-one of the 50 largest employers of research and development personnel in 1955 were not among the leaders in 1938, and an examination of their activities, as described in Moody's Industrials, shows that 19 devoted a substantial portion of their research and development effort to national defense. Eleven of these firms were in aircraft or electrical machinery where the level of government support has been very high, ${ }^{15}$ and a substantial share of the activities of the other 8 firms probably was financed by the government. If the influence of government financing of research and development were removed, it is likely that many of the 26 consistent leaders appearing in the lower half of the 1955 list, receiving only small assistance from the government, would have appeared in the first 50, replacing firms benefiting heavily from government support. ${ }^{16}$

\footnotetext{
${ }^{14}$ Recognizing mergers and treating the parent and merged firm as one firm throughout the period changes the figures to 82 per cent in 1927,84 per cent in 1938,78 per cent in 1950 , and 68 per cent in 1955 .

${ }^{15}$ Scientific Research and Development in American Industry, Table C-17, pp. 76-77.

${ }^{16}$ Blank and Stigler claim to have discovered a moderately strong substitution effect of government-financed for privately-financed research in the postwar data (op. cit., pp. 57-62). Given sufficient strength, this effect could modify our conclusion. However, the writer believes that the importance of a substitution effect can be overstated, especially as applied to the aircraft industry, whose overall condition varies with the level of government support.
} 


\section{Factors Affecting Leadership in Research and Development}

Although we have indicated that the postwar expansion of government support was responsible for some changes in the firm and industry distribution of the 100 largest, we have not assessed the role of other factors enabling firms to appear among the leaders. With our present restricted knowledge of forces determining the extent to which firms choose to engage in research and development, and with the limitations of our statistical data, we cannot hope to explore the determinants of leadership adequately. Nevertheless, modest progress may be made by examining the influence of size of firm and of industry orientation and by seeking to make some judgment about the relative strength of each influence. This is the task of this section.

\section{SIZE OF FIRM}

Our earlier examination of the size distribution of the leaders suggests that, with few exceptions (some of which are probably explained by government support), moderately large to large size appears to have been a necessary qualification for leadership. This is not surprising for, apart from any question of willingness to spend heavily on research and development, the larger size of these firms measures their ability to devote resources to this activity. Indeed we must recognize that, though most of the research and development leaders were among the largest firms, there exists considerable room for other influences to have been exerted and for the association between size of firm and employment of research and development personnel itself to vary. Consequently we must look further to discover any more fundamental effect of size.

Rank order correlations between asset size and employment of research and development personnel for those leaders for which assets data are available are given in the next tabulation. ${ }^{17}$

$\begin{array}{ccc}\text { Year } & \text { Number of Firms } & \text { Correlation Coefficients } \\ 1927 & 79 & +0.32 \\ 1938 & 86 & +0.59 \\ 1950 & 95 & +0.45 \\ 1955 & 96 & +0.47\end{array}$

The correlations suffer from the use of assets to measure the size of

${ }^{17}$ We use rank order correlations to avoid spurious values that might otherwise occur because of great differences in asset size among firms. 
firms in diverse lines of activity. Also, variations in the level of government support may have depressed the postwar values if, as seems likely, they had the effect of raising the research and development rank of smaller companies in heavily supported industries, thereby lowering the rank of larger companies not so dependent upon government support. However, to the extent that they are valid, the coefficients indicate an association between the rank order of assets and of research and development employment which is positive but not particularly strong. If we confine our calculations to the consistent members we obtain the results below. ${ }^{18}$

$\begin{array}{ccc}\text { Year } & \text { Number of Firms } & \text { Correlation Coefficients } \\ 1927 & 31 & +0.44 \\ 1938 & 52 & +0.57 \\ 1950 & 57 & +0.56 \\ 1955 & 55 & +0.68\end{array}$

They suggest a stronger relationship between size and research and development employment for the consistent leaders than for all leaders, as might be expected. Still a large portion of the variance in research and development employment is left unexplained (although the increased strength of the association in later years should be noted).

Our final set of correlations, below, is based upon firms ranking highest in asset value, in eight industry groups, ${ }^{19}$ for which research and development data are also available. Except for transportation equipment in 1950, the correlations are significant at the 5 per cent level.

\begin{tabular}{lcccc} 
& \multicolumn{2}{c}{$\begin{array}{c}\text { Number of } \\
\text { Firms }\end{array}$} & \multicolumn{2}{c}{$\begin{array}{c}\text { Correlation } \\
\text { Coefficients }\end{array}$} \\
Industry Group & 1950 & 1955 & 1950 & 1955 \\
d kindred products & 25 & 25 & +0.57 & +0.50 \\
ls and allied products & 29 & 29 & +0.57 & +0.66 \\
m and petroleum products & 30 & 25 & +0.90 & +0.92 \\
ay, and glass products & 18 & 17 & +0.63 & +0.57 \\
metals & 25 & 24 & +0.65 & +0.57 \\
ry (except electrical) & 25 & 26 & +0.40 & +0.58 \\
machinery & 25 & 25 & +0.59 & +0.50 \\
rtation equipment & 25 & 29 & +0.36 & +0.54
\end{tabular}

Food and kindred products

Chemicals and allied products

Petroleum and petroleum products

Stone, clay, and glass products

Primary metals

Machinery (except electrical)

Electrical machinery

Transportation equipment

${ }^{18}$ Here the effects of government support may be less important, since firms that appeared for the first time in the postwar period are excluded.

${ }^{19}$ Other industry groups were excluded either because of an insufficient number of large firms or because research and development data were not available for a sufficient number of firms. 
Most prominent is the strong association in the petroleum industry, where more than 80 per cent of the variance is explained by rank order of asset size. Size is less important in other industry groups, however, accounting for from 16 to 44 per cent of the variance.

We may infer from the foregoing evidence that, among the largest firms in an industry group, there exists a tendency for research and development employment to increase with size, but that the strength of the association varies among industries and is not particularly strong except in petroleum. There also exists a tendency for the 100 research and development leaders, and for the consistent leaders, to be ranked according to their size, but again the relationship is not overly strong. Thus, while size of firm apparently has contributed to the determination of the leading employers of research and development personnel it is by no means a complete explanation.

\section{RESEARCH INTENSITY}

We have observed that several industry groups played a dominant role in the nation's research and development effort from 1927 to 1955. This reflects the fact that these groups were more research-intensive than others. The research intensity of each industry group is revealed by weighting its research and development data by the value added by manufacture, thereby removing effects of differences in industry size. ${ }^{20}$ Four industry groups-chemicals, rubber, petroleum, and machinery (which, according to the census classification employed at that time, also included electrical machinery) - far exceeded others in the relative number of personnel devoted to research in 1927. These groupstogether with stone, clay, and glass products, and professional and scientific instruments (included in the miscellaneous census category) -led in 1938. Transportation equipment, electrical machinery, professional and scientific instruments, petroleum, and chemicals led in 1953.

Industry differences in research intensity are further substantiated by an analysis of the variance ratio $\mathrm{F}$ - which compares the variances in intensity between firms in different industries and those in the same industry-for 94 medium-sized firms in the eight industry groups for

${ }^{20}$ For 1927 and 1938 we used Perazich and Field's data on research and development employment by industry group (op. cit.), dividing this by value-added data for 1927 and 1937 obtained from the Census Bureau's Biennial Census of Manufactures. For 1953 we used the expenditures data in the National Science Foundation survey (op. cit.) and the value added data in the 1954 Census of Manufactures. 
which previous calculations were made. ${ }^{21}$ The $F$ value obtained from data for 1955 is sufficiently high to warrant rejecting the null hypothesis that the true $F$ value is one at the 1 per cent level of significance. Thus we may infer that there is an industry effect upon the intensity of research effort.

\section{SIZE VERSUS INDUSTRY ORIENTATION}

Since both size of firm and industry research intensity have helped to determine the leaders it is interesting to speculate about which effect has displayed the greater relative strength. We may gain some perspective on this point by extending our earlier comparison of the 100 research and development leaders and the 100 largest firms. Table 3 shows the industry distribution of firms in both sets of lists. It is immediately clear that the relative contributions of various industry groups to each list varied widely and that firms in the more researchintensive industry groups appeared among the leading employers of research and development personnel in considerably greater frequency, and with greater weight, than their asset size might justify. The petroleum industry is the only exception in that, although it was one of the leaders in research and development in all years, it was relatively less significant in the lists of the research and development leaders than it was in the lists of the largest firms. Although this may have occurred in part because the industry is capital intensive and thereby acquires an exaggerated influence when assets are chosen to measure size, its research and development significance in 1955 is only slightly greater than its size significance if we determine the 100 largest firms on the basis of their total employment. ${ }^{22}$

Antithetical situations - cases where firms and industries occupied a more important place in the lists of the largest firms than in the lists of the research and development leaders-are equally important. Primary metals is the leading example. While a number of firms in this industry group were among the leaders at various times, they were never very important. Indeed, by 1955 only 3 firms from this groupeach in a different subgroup-appeared, and they accounted collectively for only 1.34 per cent of the total research and development

${ }^{21}$ Medium-sized firms were chosen for analysis because differences in firm sizes between industries are much more marked in the larger size range. Therefore intensity differences would be clouded by the effects of size if calculations were based upon the largest firms. Size differences still remain but they have been minimized as much as possible.

The writer is indebted to Mamoru Ishikawa for suggesting and conducting the F test.

${ }^{22}$ The reverse is true for transportation equipment, mainly because firms in the aircraft industry rank higher when measured by employment than when measured by assets. 
TABLE 3

Comparison of the 100 Largest Employers of Research and Development Personnel with the 100 Largest Firms (on an Asset Basis), by Industry Group

\begin{tabular}{|c|c|c|c|c|c|c|c|c|}
\hline \multirow[b]{2}{*}{ INDUSTRY GROUP } & \multicolumn{8}{|c|}{100 LARGEST FIRMS } \\
\hline & $\begin{array}{c}\text { Num- } \\
\text { ber } \\
\text { of } \\
\text { Firms }\end{array}$ & $\begin{array}{l}1929 \\
\text { Per Cent } \\
\text { of Assets } \\
\text { of } 100 \\
\text { Largest }\end{array}$ & $\begin{array}{c}\begin{array}{c}\text { Num- } \\
\text { ber } \\
\text { of } \\
\text { Firms }\end{array}\end{array}$ & $\begin{array}{l}1935 \\
\text { Per Cent } \\
\text { of Assets } \\
\text { of } 100 \\
\text { Largest }\end{array}$ & $\begin{array}{c}\text { Num- } \\
\text { ber } \\
\text { of } \\
\text { Firms }\end{array}$ & $\begin{array}{l}1948 \\
\text { Per Cent } \\
\text { of Assets } \\
\text { of } 100 \\
\text { Largest }\end{array}$ & $\begin{array}{c}\begin{array}{c}\text { Num- } \\
\text { ber } \\
\text { of } \\
\text { Firms }\end{array}\end{array}$ & $\begin{array}{l}1955 \\
\text { Per Cent } \\
\text { of Assets } \\
\text { of } 100 \\
\text { Largest }\end{array}$ \\
\hline $\begin{array}{l}\text { Food and kindred } \\
\text { products }\end{array}$ & 10 & 7.17 & 10 & 6.63 & 11 & 6.81 & 9 & 4.19 \\
\hline $\begin{array}{l}\text { Tobacco } \\
\text { manufactures }\end{array}$ & & & & & & & & \\
\hline manufactures & 4 & 2.42 & 3 & 2.36 & 3 & 3.35 & 4 & 2.48 \\
\hline Textile mill products & 1 & 0.40 & 0 & 0.00 & 3 & 1.21 & 3 & 1.38 \\
\hline $\begin{array}{l}\text { Lumber and lumber } \\
\text { products (except } \\
\text { furniture) }\end{array}$ & 1 & 0.41 & 0 & 0.00 & 1 & 0.43 & 0 & 0.00 \\
\hline $\begin{array}{l}\text { Paper and allied } \\
\text { products }\end{array}$ & 2 & 1.40 & 5 & 2.32 & 2 & 0.98 & 3 & 1.52 \\
\hline $\begin{array}{l}\text { Printing and pub- } \\
\text { lishing industries }\end{array}$ & 0 & 0.00 & 1 & 0.52 & 1 & 0.33 & 0 & 0.00 \\
\hline $\begin{array}{l}\text { Chemicals and allied } \\
\text { products }\end{array}$ & 5 & 4.71 & 4 & 4.94 & 8 & 7.07 & 10 & 10.10 \\
\hline $\begin{array}{l}\text { Petroleum and coal } \\
\text { products }\end{array}$ & 20 & 28.36 & 17 & 28.23 & 17 & 28.78 & 21 & 32.15 \\
\hline Rubber products & 4 & 3.07 & 4 & 2.47 & 4 & 2.81 & 4 & 2.91 \\
\hline $\begin{array}{l}\text { Leather and leather } \\
\text { products }\end{array}$ & 1 & 0.39 & 1 & 0.33 & 0 & 0.00 & 0 & 0.00 \\
\hline $\begin{array}{l}\text { Stone, clay, and } \\
\text { glass products }\end{array}$ & 1 & 0.36 & 1 & 0.44 & 2 & 0.83 & 2 & 0.99 \\
\hline $\begin{array}{l}\text { Primary metal } \\
\text { products }\end{array}$ & 17 & 22.32 & 19 & 23.15 & 16 & 17.65 . & 18 & 16.94 \\
\hline $\begin{array}{l}\text { Fabricated metal } \\
\text { products }\end{array}$ & 1 & 0.67 & 2 & 1.22 & 2 & 1.01 & 2 & 1.00 \\
\hline $\begin{array}{l}\text { Machinery (except } \\
\text { electrical) }\end{array}$ & 4 & 3.20 & 7 & 4.18 & 6 & 3.66 & 7 & 4.39 \\
\hline Electrical machinery & 3 & 3.26 & 3 & 2.78 & 3 & 4.32 & 3 & 4.29 \\
\hline $\begin{array}{l}\text { Transportation } \\
\text { equipment } \\
\text { Instruments and }\end{array}$ & 8 & 10.77 & 6 & 11.27 & 6 & 10.57 & 11 & 14.64 \\
\hline $\begin{array}{l}\text { related products } \\
\text { Miscellaneous }\end{array}$ & 1 & 0.57 & 1 & 0.67 & 1 & 0.84 & 1 & 0.71 \\
\hline $\begin{array}{l}\text { manufactures } \\
\text { Nonmanufacturing }\end{array}$ & $\begin{array}{r}1 \\
16\end{array}$ & $\begin{array}{l}0.76 \\
9.77\end{array}$ & $\begin{array}{r}0 \\
16\end{array}$ & $\begin{array}{l}0.00 \\
8.54\end{array}$ & $\begin{array}{r}0 \\
14\end{array}$ & $\begin{array}{l}0.00 \\
9.33\end{array}$ & $\begin{array}{l}0 \\
2\end{array}$ & $\begin{array}{l}0.00 \\
2.26\end{array}$ \\
\hline
\end{tabular}

employment of the 100 largest. We may speculate that the sheer size of these firms was sufficient to insure a place for them among the research and development leaders despite the fact that they were not heavily research intensive. There are a number of other cases-e.g., food and kindred products, tobacco, textiles, paper-less marked than that of primary metals, where size of firm was not matched by 
TABLE 3 (concluded)

100 LARGEST R AND D EMPLOYERS

\begin{tabular}{|c|c|c|c|c|c|c|c|}
\hline $\begin{array}{l}\text { Num- } \\
\text { ber } \\
\text { of } \\
\text { Firms }\end{array}$ & $\begin{array}{l}1927 \\
\text { Per Cent of } \\
\text { RD Personnel } \\
\text { of } 100 \\
\text { Largest }\end{array}$ & $\begin{array}{l}\text { Num- } \\
\text { ber } \\
\text { of } \\
\text { Firms }\end{array}$ & $\begin{array}{l}1938 \\
\text { Per Cent of } \\
\text { RD Personnel } \\
\text { of } 100 \\
\text { Largest }\end{array}$ & $\begin{array}{l}\text { Num- } \\
\text { ber } \\
\text { of } \\
\text { Firms }\end{array}$ & $\begin{array}{l}1950 \\
\text { Per Cent of } \\
\text { RD Personnel } \\
\text { of } 100 \\
\text { Largest }\end{array}$ & $\begin{array}{l}\text { Num- } \\
\text { ber } \\
\text { of } \\
\text { Firms }\end{array}$ & $\begin{array}{l}1955 \\
\text { Per Cent of } \\
\text { RD Personnel } \\
\text { of } 100 \\
\text { Largest }\end{array}$ \\
\hline 3 & 0.74 & 6 & 1.88 & 6 & 2.18 & 3 & 1.04 \\
\hline 0 & 0.00 & 0 & 0.00 & 0 & 0.00 & 0 & 0.00 \\
\hline 1 & 0.37 & 1 & 0.32 & 1 & 0.41 & 1 & 0.36 \\
\hline 0 & 0.00 & 0 & 0.00 & 0 & 0.00 & 0 & 0.00 \\
\hline 2 & 0.87 & 2 & 0.43 & 0 & 0.00 & 0 & 0.00 \\
\hline 0 & 0.00 & 0 & 0.00 & 0 & 0.00 & 0 & 0.00 \\
\hline 20 & 19.89 & 23 & 21.61 & 23 & 18.87 & 20 & 14.85 \\
\hline 11 & 11.60 & 13 & 16.34 & 12 & 14.71 & 13 & 10.31 \\
\hline 7 & 8.97 & 5 & 7.03 & 4 & 3.94 & 5 & 6.70 \\
\hline 0 & 0.00 & 0 & 0.00 & 0 & 0.00 & 0 & 0.00 \\
\hline 7 & 2.13 & 8 & 2.87 & 5 & 2.49 & 3 & 0.93 \\
\hline 12 & 4.21 & 11 & 6.50 & 4 & 2.05 & 3 & 1.34 \\
\hline 2 & 0.57 & 2 & 0.84 & 4 & 1.73 & 3 & 1.03 \\
\hline $\begin{array}{r}11 \\
9\end{array}$ & $\begin{array}{r}8.58 \\
13.47\end{array}$ & $\begin{array}{l}6 \\
9\end{array}$ & $\begin{array}{r}4.03 \\
11.37\end{array}$ & $\begin{array}{r}5 \\
12\end{array}$ & $\begin{array}{r}2.55 \\
15.83\end{array}$ & $\begin{array}{r}7 \\
16\end{array}$ & $\begin{array}{r}6.38 \\
19.06\end{array}$ \\
\hline 7 & 5.90 & 5 & 7.42 & 17 & 22.56 & 19 & 28.00 \\
\hline 3 & 1.82 & 2 & 1.55 & 4 & 2.96 & 4 & 2.42 \\
\hline 0 & 0.00 & 0 & 0.00 & 0 & 0.00 & 0 & 0.00 \\
\hline 5 & 20.86 & 7 & 17.81 & 3 & 9.73 & 3 & 7.61 \\
\hline
\end{tabular}

proportionate representation in the research and development lists. Industry influences (especially the heavy representation of firms in chemicals and petroleum) are also evident in the distribution of the consistent leaders in research and development, as the next tabulation shows. 


\section{Industry Group}

Food and kindred products

Chemicals and allied products

Petroleum and petroleum products

Rubber products

Stone, clay, and glass products

Primary metals

Fabricated metal products

Machinery (except electrical)

Electrical machinery

Transportation equipment

Instruments and related products

Nonmanufacturing (electrical communication)
Number of Firms Appearing in: Four Lists Three Lists Total

We see also that firms in industry groups not heavily characterized by research and development activity were present. Here again sheer size may have been an important determinant, although it is also possible that a factor which we cannot hope to measure may have been operative-i.e., that there have been important differences in the extent to which entrepreneurs perceived the wisdom of creating and exploiting research and development opportunities.

Which effect has been relatively more important? The writer believes that the evidence supports the judgment that the industry in which firms were located has been the dominant factor determining the extent to which they engaged in research and development and that, subject to this overriding influence, their size played a secondary role. As to the underlying reasons for differences in research intensity among industries, we may observe that our findings are generally consistent with those in the studies of patent statistics by Stafford and Schmookler; namely, that the portion of inventive activity that is patentable is concentrated in areas directly related to chemistry and physics and that a large part of inventive activity is generated by a "technological elite." 23

\footnotetext{
${ }^{23}$ Alfred B. Stafford, "An Appraisal of Patent Statistics;" Jacob Schmookler, "Technical Change and Patent Statistics." These mongraphs were presented to the Conference on Quantitative Description of Technological Change, sponsored by the Committees on Economic Growth and on Social Implications of Atomic Energy and Technological Change of the Social Science Research Council, 1951.
} 


\section{Conclusion}

Our purpose has been to analyze the changing direction of research and development employment among firms, concentrating upon the composition of the 100 leading employers in selected years from 1927 to 1955. We have shown that the leaders accounted for a substantial share of industrial research and development employment and that the 59 firms that led most frequently have been responsible for most of this share. We have also shown that the leaders have been concentrated in a few industry groups. In view of the sizeable growth in research and development that has taken place during the period under examination, one can only conclude that the pattern of leadership has displayed considerable stability.

Changes have, of course, occurred. The firms that have consistently appeared among the leaders now account for a smaller share of the total than in the past. The transportation equipment industry now occupies a dominant position in the industry-group distribution of the leaders, having replaced electrical communication among the four leading groups in the prewar lists. But these changes are largely attributable to heavy postwar government support of firms in a few industry groups and our conclusion still remains applicable as far as private forces generating research and development activity are concerned.

Of the two possible determinants of leadership examined in the paper, variations in research intensity among industries appears to have been dominant. But, since most of the leaders have come from among the larger firms in the economy and since there is some positive association between rank order of research and development employment and rank order of assets, size of firm has exercised an influence. Also, one cannot escape the feeling that entrepreneurial vision played a part. 
